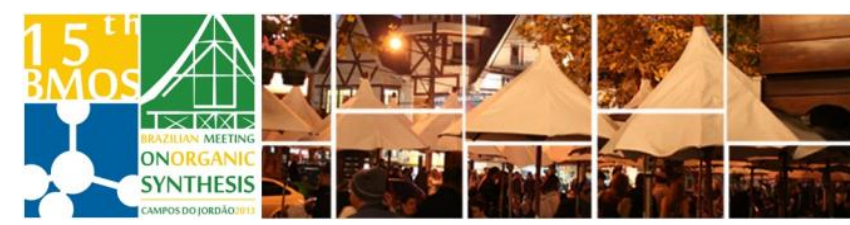

\title{
Synthesis of 2,3-Diaryl-2-azabicyclooctanones derivatives by multicomponent reaction promoted by $\mathrm{Nb}(\mathrm{OEt})_{5}$.
}

\section{Bruno Henrique Sacoman Torquato da Silva, ${ }^{*}$ Lucas Michelão Martins e Luiz Carlos da Silva-Filho.}

Laboratory of Organic Synthesis and Catalysis, POSMAT, UNESP-Bauru, Av. Eng. Luiz Edmundo Carrijo Coube, 14-01, CEP 17033-360, Vargem Limpa, Bauru, S.P.

*bruno sacoman@hotmail.com

Keywords: Niobium Pentaethoxide, Multicomponent Reaction, 2,3-Diaryl-2-azabicyclooctanones.

\section{INTRODUCTION}

The 2,3-Diaryl-2-azabicyclooctanones derivatives (1) can be synthetized by Povarov Multicomponent Reaction (MCR) using a Lewis Acid as reaction promoter. ${ }^{1,2}$ The Povarov MCRs are defined as a process in which three or more reagents are combined in the same reaction "pot" generating the products with good structural complexity, with characteristics of each reagent used and in a single step.

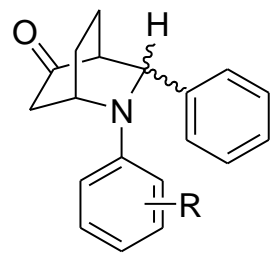

Figure 1. 2,3-Diaryl-2-azabicyclooctanones derivatives.

In studies recently found in the literature, ${ }^{1,2}$ we can observe the good applicability of 2,3-Diaryl-2azabicyclooctanones derivatives as possible drugs for the treatment of Alzheimers's disease. The azabicyclooctanones derivatives act by inhibiting the acetylcholinesterase (AChE), an enzyme responsible by the hydrolysis of acetylcholine in the brain. ${ }^{1,2}$

In this work we report a new method to synthesize 2,3-Diaryl-2-azabicyclooctanones derivatives through Povarov MCRs, using niobium pentaethoxide as a reaction promoter. ${ }^{3}$

\section{RESULTS AND DISCUSSION}

The MCRs were conducted between anilines derivatives $\{\mathbf{2}(\mathbf{a}-\mathbf{j})\}$, benzaldehyde (3) and ciclohexen-2-one (4), using niobium pentaethoxide. (scheme1)
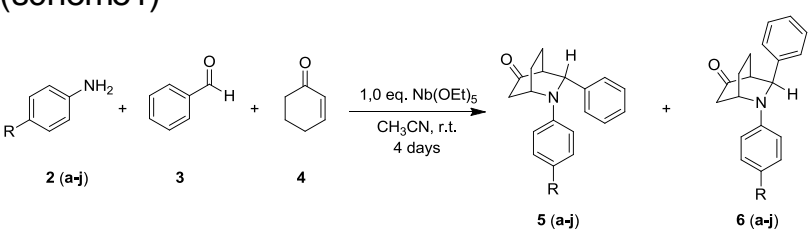

$15^{\text {th }}$ Brazilian Meeting on Organic Synthesis
Scheme 1: MCR using $\mathrm{Nb}(\mathrm{OEt})_{5}$ as promoter.

The reactions were realized at room temperature and under inert atmosphere, using anhydrous $\mathrm{CH}_{3} \mathrm{CN}$. The products obtained were isolated by silica-gel column chromatography and characterized through spectroscopic and spectrometric methods.

The results obtained are described in the table 1.

Table 1. Results obtained at MCR promoted by $\mathrm{Nb}(\mathrm{OEt})_{5}$.

\begin{tabular}{|c|c|c|c|}
\hline Aniline & $\mathbf{R}$ & Yield (\%) & $\begin{array}{c}\text { Products } \\
\text { Ratio (\%) }\end{array}$ \\
\hline $\mathbf{2 a}$ & $\mathrm{H}$ & 80 & $60: 40(\mathbf{5 a}: \mathbf{6 a})$ \\
\hline $\mathbf{2 b}$ & $\mathrm{F}$ & 94 & $49: 51(\mathbf{5 b}: \mathbf{6 b})$ \\
\hline $\mathbf{2 c}$ & $\mathrm{Cl}$ & 78 & $48: 52(\mathbf{5 c}: \mathbf{6 c})$ \\
\hline $\mathbf{2 d}$ & $\mathrm{Br}$ & 86 & $45: 55(\mathbf{5 d}: \mathbf{6 d})$ \\
\hline $\mathbf{2 e}$ & $\mathrm{I}$ & 86 & $46: 54(\mathbf{5 e}: \mathbf{6 e})$ \\
\hline $\mathbf{2 f}$ & $\mathrm{Me}$ & 93 & $61: 39(\mathbf{5 t}: \mathbf{6 f})$ \\
\hline $\mathbf{2 g}$ & $\mathrm{Et}$ & 95 & $59: 41(\mathbf{5 g}: \mathbf{6 g})$ \\
\hline $\mathbf{2 h}$ & $\mathrm{n}-\mathrm{Bu}$ & 84 & $60: 40(\mathbf{5 h}: \mathbf{6 h})$ \\
\hline $\mathbf{2 i}$ & $\mathrm{t}-\mathrm{Bu}$ & 94 & $68: 32(\mathbf{5 i} \mathbf{6} \mathbf{6 i})$ \\
\hline $\mathbf{2 j}$ & $\mathrm{OMe}$ & 74 & $57: 43(\mathbf{5} \mathbf{6} \mathbf{6 j})$ \\
\hline
\end{tabular}

Analyzing the data above, we can verify that the $\mathrm{Nb}(\mathrm{OEt})_{5}$ promotes the MCR to synthesize the 2,3Diaryl-2-azabicyclooctanones derivatives with high yield and moderate reaction time.

\section{CONCLUSION}

The results obtained in this work show that the $\mathrm{Nb}(\mathrm{OEt})_{5}$ is a good promoter to act as Lewis Acid in the preparation of 2,3-Diaryl-2-azabicyclooctanones derivatives, obtaining the products with high yield.

\section{ACKNOWLEDGEMENTS}

The authors thank the FAPESP, CAPES and CNPQ for financial support.

\section{REFERENCES}

${ }^{1}$ Borkin, D.; et al. Org. Biomol. Chem., 2011,9,1394

2 Astudilho, L. S.; Vallejos, G. A.; Correa, N.; Gutierrez, M. C.; de la

Guarda, W.; Kouznetsov, V. Letters in Organic Chemistr.. 2008 ,5, 559.

Larcerda, Jr. V.; Santos D. A.; Silva-filho, L. C.; Greco, S. J.; Santos, R.

B. Aldrichimica Acta. 2012, 45, 19 . 